\title{
Efek Waktu Tahan Pack Carburizing Terhadap Kekerasan dan Keausan Nosel Imitasi Truk Barang
}

\author{
Sigit Gunawan*1 \\ ${ }^{1}$ Teknik Mesin, Fakultas Vokasi, Institut Teknologi Nasional Yogyakarta, Indonesia \\ E-mail: '1gunruscit@gmail.com
}

\begin{abstract}
Abstrak
Penelitian ini dimaksudkan untuk mengetahui efek waktu tahan pack carburizing terhadap kekerasan dan keausan nosel imitasi truk barang. Variabel penelitian adalah waktu tahan carburizing. Variasi waktu tahan 90 , 120, 150, 180 dan 210 menit. Proses pack carburizing dilakukan dengan menggunakan media karburasi arang tempurung kelapa dan ditambahkan barium karbonat. Metode penelitian ini adalah eksperimen melalui pengujian laboratorium dengan menggunakan proses pack carburizing. Nosel kemudian dibuat spesimen untuk uji kekerasan, uji keausan dan uji struktur mikro. Spesimen dibuat dalam dua kondisi yaitu kondisi raw material dan kondisi dengan perlakuan pack carburizing. Proses pack carburizing dilakukan dengan memanaskan spesimen uji di dalam kotak tanah liat yang telah diisi campuran media pack carburizing dan barium karbonat $\left(\mathrm{BaCO}_{3}\right)$ pada suhu $900^{\circ} \mathrm{C}$ dengan variasi holding time 90, 120, 150, 180 dan 210 menit, kemudian spesimen diberi perlakuan quenching dengan cara mencelupkan ke dalam media pendingin berupa oli sampai suhu kamar. Tahap selanjutnya dilakukan pengujian kekerasan, keausan dan struktur mikro. Hasil penelitian menunjukkan bahwa kenaikan waktu tahan menyebabkan kekerasan dan keausan cenderung meningkat. Kekerasan rata-rata tertinggi 975,4 VHN pada waktu tahan 210 menit, dan ketahanan aus tertinggi 9,41701E-09 $\mathrm{mm}^{2} / \mathrm{kg}$ pada waktu tahan 150 menit. Dengan proses pack carburizing kandungan $\mathrm{C}$ meningkat sehingga merangsang terbentuknya martensit dan karbida chrom seiring lamanya waktu tahan.
\end{abstract}

Kata kunci: Karburising, Keausan, Kekerasan, Waktu Tahan

\begin{abstract}
This research was intended to determine the effect of pack carburizing holding time through the hardness and wear of the imitation truck nozzle. The research variable is the carburizing holding time. The variation of holding time are 90,120,150, 180 and 210 minutes. The pack carburizing process is carried out using coconut shell charcoal carburizing media and added the barium carbonate. This research method is an experiment through laboratory testing using the pack carburizing process. The nozzle is made into a specimen for hardness test, wear test and microstructure test. Specimens were made in two conditions, namely raw material conditions and conditions with pack carburizing treatment. The pack carburizing process is carried out by heating the test specimen in a clay box that has been filled with a mixture of pack carburizing media and barium carbonate $\left(\mathrm{BaCO}_{3}\right)$ at a temperature of $900^{\circ} \mathrm{C}$ with holding time variations of $90,120,150,180$ and 210 minutes, then the specimen is quenched by dipping into the cooling medium in the form of oil until room temperature. The next stage is testing for hardness, wear and microstructure. The results showed that the increase in the holding time caused the hardness and wear to tend to increase. The highest average hardness is 975.4 VHN at a holding time of 210 minutes, and the highest wear resistance is $9.41701 \mathrm{E}-09 \mathrm{~mm}^{2} / \mathrm{kg}$ at a holding time of 150 minutes. With the pack carburizing process, the $C$ content increases, it stimulates the formation of martensite and chrome carbide as long as the holding time.
\end{abstract}

Keywords: Carburizing, Hardness, Holding Time, Wear

\section{PENDAHULUAN}

Mesin diesel mengalami banyak inovasi sejak diperkenalkan pertama kali pada tahun 1892 di Jerman oleh Rudolf Diesel. Berbagai riset dan penelitian memberikan perkembangan yang cukup signifikan terutama pada tingkat konsumsi bahan bakar, efisiensi struktur dan komponen mekanis, hingga penggunaan bahan bakar yang lebih ramah lingkungan. Kenyataan di lapangan menunjukkan 
bahwa kegagalan komponen mesin disebabkan oleh kerusakan pada permukaan berupa keausan, retak maupun korosi. Keausan didefinisikan sebagai kerusakan pada permukaan material padat yang diakibatkan oleh pengurangan atau perpindahan material melalui aksi mekanis dari material lain baik padat, cair atau gas yang bersentuhan dengannya (ASM Handbook, 1990). Keausan merupakan faktor penting dalam mengurangi fungsi permesinan termasuk membatasi usia pemakaian. Hal ini mengakibatkan peningkatan biaya maintenance.

Nosel merupakan salah satu komponen penting pada sistem bahan bakar mesin diesel. Nosel pada mesin diesel berfungsi sebagai pengatur masuknya bahan bakar ke dalam ruang bakar. Udara dari luar yang dikompresikan sampai tekanan tertentu, kemudian bahan bakar disemprotkan dalam udara yang bertekanan dan kecepatan tinggi sehingga langsung terjadi pembakaran. Material untuk membuat nosel harus mempunyai ketahanan aus yang cukup tinggi. Untuk mendapatkan sifat yang demikian, maka bahan perlu diberikan perlakuan panas. Pada dasarnya perlakuan panas adalah proses memanaskan bahan sampai suhu tertentu dalam jangka waktu tertentu, kemudian didinginkan dengan metode tertentu. Salah satu cara yang dapat dilakukan untuk meningkatkan sifat-sifat permukaan adalah dengan proses carburizing. Carburizing dapat meningkatkan kekerasan permukaan sehingga lebih tahan aus yang diikuti dengan peningkatan umur komponen.

Karburasi atau Carburizing adalah proses pemberian atau penambahan kandungan karbon yang lebih banyak pada bagian permukaan dibanding dengan dinding bagian dalam, sehingga kekerasan permukaannya lebih meningkat. Sedangkan pada bagian dalamnya diharapkan masih memiliki keuletan atau keliatan (Palallo, 1995).

Saputro, dkk (2019) meneliti mengenai analisis pengaruh holding time terhadap kekerasan baja AISI 4140 dengan metode pack carburizing dengan media arang bambu. Hasil penelitian menginformasikan peningkatan kekerasan dengan bertambahnya holding time, nilai kekerasan tertinggi diperoleh pada holding time 120 menit. Dwiyati, dkk (2019) telah meneliti pengaruh variasi holding time dan media quenching terhadap nilai kekerasan baja dengan kadar karbon 0,192 wt \% dan diperoleh hasil bahwa semakin lama holding time maka kekerasan semakin naik.

Rasid, dkk (2018) telah melakukan penelitian tentang pengaruh proses pack carburizing menggunakan media batubara terhadap kekerasan pisau kuduk dan diperoleh hasil bahwa proses pack carburizing dengan suhu $900^{\circ} \mathrm{C}$ dengan variasi holding time 90, 120, dan 150 menit diikuti dengan media quenching oli bekas dapat meningkatkan kekerasan permukaan pisau kuduk yang berbahan baja karbon sedang. Sunardi, dkk (2013) meneliti tentang pengaruh pack carburizing dan kekasaran permukaan terhadap umur fatik material poros baja S45C dan diperoleh kesimpulan bahwa perlakuan pack carburizing memberikan dampak penurunan terhadap umur lelahnya, meskipun terjadi peningkatan kekerasan. Adding (2010) menemukan peningkatan kekerasan baja yang dikarburasi menggunakan kayu bakau pada suhu $900^{\circ} \mathrm{C}$ dengan waktu penahanan 5 jam yaitu $66 \mathrm{HRC}$, sedangkan baja yang dikarburasi lanjut quench pada suhu dan waktu penahanan yang sama yaitu 68,5 HRC.

Kuswanto (2010) telah meneliti perlakuan pack carburizing pada baja karbon rendah sebagai material alternatif untuk pisau potong pada penerapan teknologi tepat guna dan diperoleh hasil bahwa harga kekerasan naik 26\% dan kedalaman atom karbon yang berhasil berdifusi juga cukup untuk kepentingan teknik yaitu $\pm 1000 \mu \mathrm{m}$. Hamzah dan Iqbal (2008) meneliti mengenai peningkatan ketahanan aus baja karbon rendah dengan metode carburizing. Hasil penelitian memperlihatkan bahwa semakin tinggi temperatur proses carburizing akan menghasilkan ketahanan aus spesifik yang lebih baik dan pada proses carburizing dengan temperatur $950^{\circ} \mathrm{C}$ yang dilanjutkan dengan proses pengerasan pada temperatur $840^{\circ} \mathrm{C}$ memberikan peningkatan ketahanan aus tertinggi sebesar $83,6 \%$ dibandingkan dengan ketahanan aus raw material.

Penelitian ini mencoba untuk mengungkapkan efek waktu tahan carburizing terhadap kekerasan dan keausan nosel imitasi truk barang. Dengan demikian, hasil penelitian dapat memberikan informasi bagi industri untuk mengetahui kekerasan dan keausan bahan sebagai fungsi waktu tahan carburizing.

\section{METODE PENELITIAN}

\subsection{Bahan Penelitian}


Bahan penelitian yang digunakan adalah nosel imitasi truk barang. Komposisi kimia yang terkandung di dalamnya adalah $94,848 \% \mathrm{Fe}, 0,028 \% \mathrm{~S}, 0,206 \% \mathrm{C}, 1,982 \% \mathrm{Ni}, 0,203 \% \mathrm{Si}, 1,849 \% \mathrm{Cr}$, 0,542\% Mn, 0,059\% Mo, dan 0,019\% P termasuk baja karbon rendah. Media caburizing yang digunakan yaitu arang tempurung kelapa dan energizer barium karbonat. Nosel kemudian dibuat spesimen untuk uji kekerasan, uji keausan dan uji struktur mikro. Spesimen dibuat dalam dua kondisi yaitu kondisi raw material dan kondisi dengan perlakuan pack carburizing.

Proses pack carburizing dilakukan dengan memanaskan spesimen uji di dalam kotak tanah liat yang telah diisi campuran media pack carburizing dan barium karbonat $\left(\mathrm{BaCO}_{3}\right)$ pada suhu $900^{\circ} \mathrm{C}$ dengan variasi holding time 90, 120, 150, 180 dan 210 menit, kemudian spesimen diberi perlakuan quenching dengan cara mencelupkan ke dalam media pendingin berupa oli sampai suhu kamar.

\subsection{Alat yang digunakan}

a. Furnaceloven merk Nabertherm tipe L3/12/C6.

b. Mesin uji kekerasan micro vickers merk micromet.

c. Mikroskop optik model PME3-313UN, merk Olympus dengan kemampuan perbesaran 100, 200, 500, dan 1000 kali.

d. Alat uji keausan merk Ogoshi High Speed Universal Wear Testing Machine tipe OAT-U.

e. Kotak karburasi.

f. Alat pemotong logam.

g. Kertas amplas, autosol, dan larutan etsaBahan.

\subsection{Pelaksanaan Penelitian}

Diagram alir penelitian sebagai tahap kegiatan ditunjukkan pada Gambar 1.

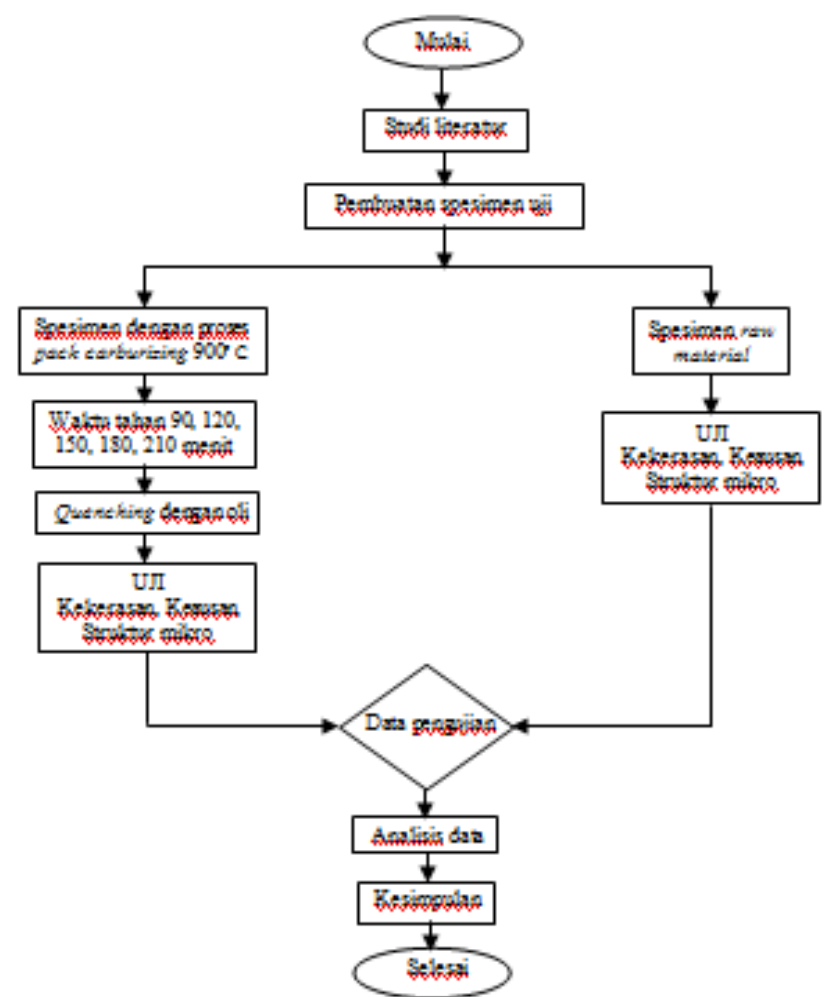

Gambar 1. Diagram Alir Penelitian

Pengujian kekerasan dilakukan dengan metode kekerasan micro vickers dengan beban indentasi 200 gr. Penetrator piramid intan ditekankan kepermukaan yang akan diukur kemudian dicari panjang diagonal rata-ratanya. Sebelumnya permukaan spesimen dihaluskan dengan kertas amplas no. 120, 
200, 400, 600, dan 1000. Selanjutnya dilakukan lagi penghalusan menggunakan autosol sampai bekas goresan-goresan hilang.

Pengujian keausan dilakukan dengan cara menggesekkan piringan berputar terhadap spesimen. Pengujian keausan dilakukan dengan mesin uji Ogoshi High Speed Universal Wear Testing Machine Tipe OAT-U. Pengujian keausan mengacu pada metode Reiken Ogoshi dengan lebar piringan pengaus $3 \mathrm{~mm}$, jari-jari pengaus $14,4 \mathrm{~mm}$, beban tekan pada pengaus $2,21 \mathrm{~kg}$, jarak tempuh selama proses pengausan $100 \mathrm{~m}$ dengan waktu pengausan 41 detik. Lebar keausan pada permukaan spesimen diukur dengan bantuan miskroskop optik.

Struktur mikro diamati dengan miskroskop optik perbesaran 200 kali. Sebelumnya permukaan spesimen dihaluskan dengan amplas no. 120, 200, 400, 600, dan 1000. Setelah permukaan halus, dilakukan lagi penghalusan menggunakan autosol sampai permukaan menjadi mengkilat, kemudian dietsa dengan larutan etsa $\left(\mathrm{HNO}_{3}+\right.$ Etanol).

\section{HASIL DAN PEMBAHASAN}

Hubungan antara waktu tahan pack carburizing dan kekerasan diperlihatkan pada Gambar 2.

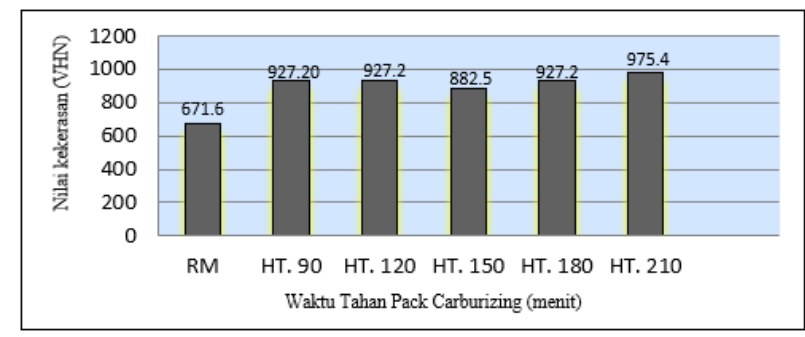

Gambar 2. Grafik hubungan antara waktu tahan pack carburizing dan kekerasan

Gambar 2 memperlihatkan bahwa nilai kekerasan rata-rata tertinggi adalah 975,4 VHN diperoleh pada spesimen yang mendapat perlakuan pack carburizing dengan waktu tahan 210 menit. Hal ini disebabkan oleh terbentuknya struktur martensit dan karbida chrom yang cukup mendominasi dan merata di permukan bahan. Kekerasan rata-rata terendah adalah 671,6 VHN diperoleh pada spesimen raw material. Secara umum terlihat bahwa semakin lama waktu tahan menyebabkan kekerasan permukaan bahan semakin meningkat, karena semakin banyak martensit dan karbida chrom yang terbentuk.

Hubungan antara waktu tahan pack carburizing dan keausan ditunjukkan pada Gambar 3.

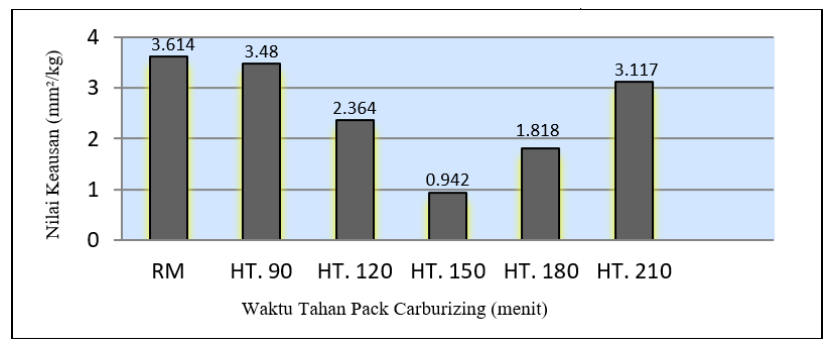

Keterangan: dikali $10^{-8}$

Gambar 3. Grafik hubungan antara waktu tahan pack carburizing dan keausan

Gambar 3 menunjukkan keausan dari spesimen raw material dan spesimen yang telah mendapat proses pack carburizing dengan variasi waktu tahan pack carburizing. Hasil uji keausan memperlihatkan bahwa keausan tertinggi diperoleh pada spesimen bahan asal, yaitu 3,614 x $10^{-8}$ $\mathrm{mm}^{2} / \mathrm{kg}$. Hasil uji keausan setelah mendapat perlakuan pack carburizing menunjukkan bahwa terjadi penurunan laju keausan dibanding dengan raw material. Spesimen yang diberi perlakuan pack carburizing dengan waktu tahan 150 menit memiliki keausan terkecil yaitu $0,942 \times 10^{-8} \mathrm{~mm}^{2} / \mathrm{kg}$ dibanding dengan semua proses pack carburizing. Waktu tahan 180 menit dan waktu tahan lebih lama 
(210 menit) terjadi peningkatan keausan yang dapat dipengaruhi oleh terjadinya over heating, sehingga semakin banyak struktur martensit yang terbentuk yang menyebabkan bahan menjadi getas sehingga ketahanan ausnya berkurang.

Gambar 4 memperlihatkan hasil pengujian struktur mikro. Hasil pengujian foto mikro menginformasikan bahwa struktur mikro bahan asal adalah ferit dan perlit. Ferit merupakan unsur besi murni berwarna terang dan cenderung lebih halus dan lunak. Perlit berwarna lebih gelap, lebih kasar dan lebih keras karena lebih banyak mengandung karbon. Dari bentuk kristal yang seragam, maka diperkirakan bahan raw material tidak mendapatkan perlakuan panas sebelumnya. Proses pack carburizing dengan waktu tahan 90 menit terlihat masuknya unsur $\mathrm{C}$ dan membentuk martensit. Struktur mikronya adalah martensit, ferit, perlit dan sedikit karbida chrom. Tingkat kekerasanya cukup tinggi, karena terbentuknya struktur martensit. Pada foto mikro waktu tahan 120 menit struktur mikronya adalah martensit, ferit, perlit dengan karbida chrom yang belum banyak. Terlihat masuknya unsur C semakin banyak. Spesimen yang mendapat perlakuan pack carburizing waktu tahan 150 menit struktur mikronya masih berisi martensit, ferit, perlit dan karbida chrom mulai terlihat dominan. Perlakuan pack carburizing dengan waktu ahan 180 menit terlihat penetrasi unsur $\mathrm{C}$ semakin dalam dan menghasilkan striktur mikro martensit, ferit dan perlit dengan karbida chrom cukup banyak. Struktur mikro spesimen yang mendapat perlakuan pack carburizing dengan waktu tahan 210 menit terlihat unsur C semakin banyak dan semakin dalam. Struktur mikro berisi martensit, ferit, perlit dan didominasi oleh karbida chrom pada permukaan benda secara merata. Hal ini menyebabkan kekerasan cenderung naik.

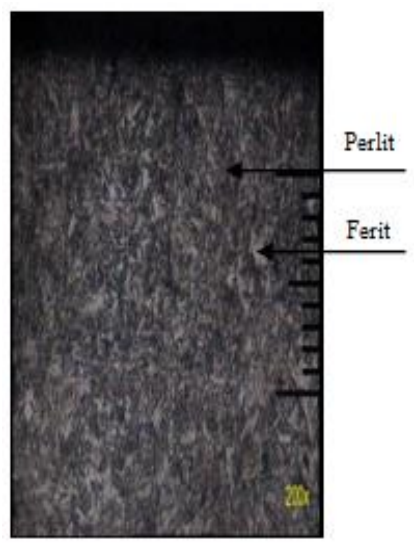

a). Raw material

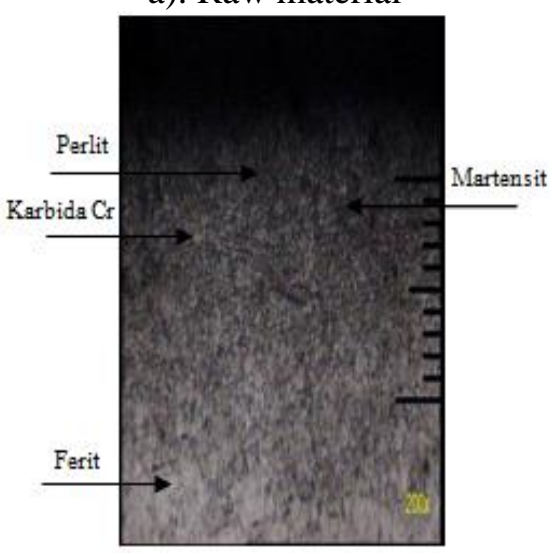

c). Spesimen dengan HT. 120 menit

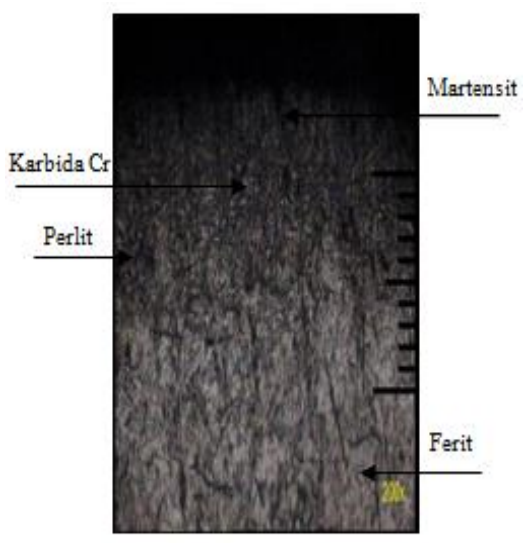

b). Spesimen dengan HT. 90 menit

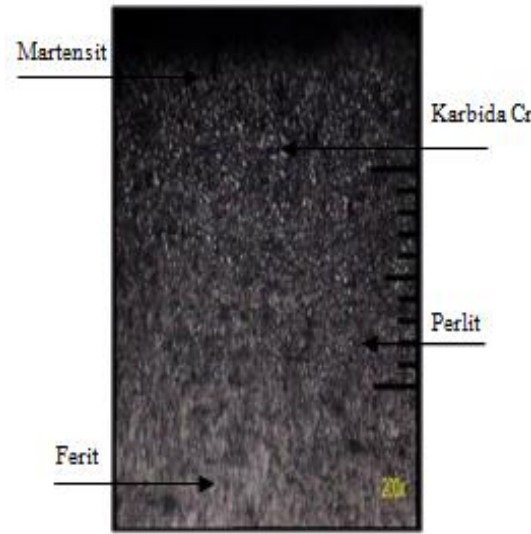

d). Spesimen dengan HT. 150 menit 


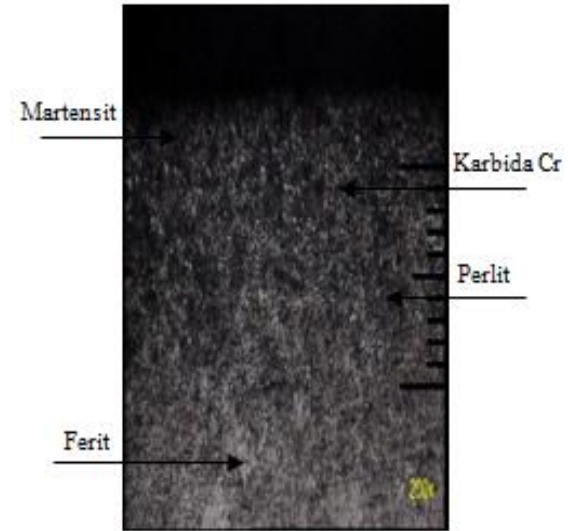

e). Spesimen dengan HT. 180 menit

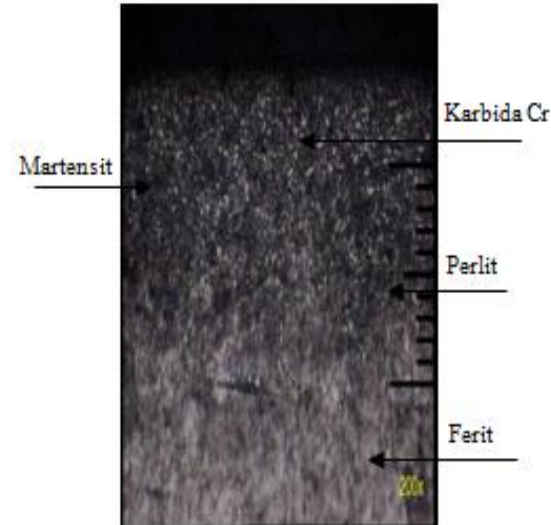

f). Spesimen dengan HT. 210 menit

Gambar 4. Hasil pengujian struktur mikro

\section{KESIMPULAN}

Kekerasan raw material adalah 671,6 VHN. Hasil uji kekerasan setelah diberi perlakuan pack carburizing menunjukkan bahwa kekerasan rata-rata tertinggi 975,4 VHN diperoleh pada waktu tahan 210 menit dan kekerasan rata-rata terendah diperoleh pada waktu tahan 150 menit, yaitu 882,5 VHN. Kenaikan waktu tahan menyebabkan kekerasan meningkat.

Ketahanan aus tertinggi 9,41701E-09 $\mathrm{mm}^{2} / \mathrm{kg}$ diperoleh pada waktu tahan 150 menit. Waktu tahan 210 menit telah terjadi over heating yang menyebabkan bahan menjadi getas ditandai dengan naiknya laju keausan bahan. Kenaikan waktu tahan menyebabkan keausan cenderung meningkat.

Hasil uji struktur mikro memperlihatkan bahwa struktur mikro raw material adalah ferit dan perlit. Butiran ferit berbentuk serpih tidak terlalu besar sehingga harga kekerasan cukup tinggi walaupun kadar karbon rendah. Hal ini disebabkan karena kadar unsur chrom dan nikel cukup tinggi. Seiring naiknya waktu tahan proses pack carburizing menyebabkan kandungan $\mathrm{C}$ meningkat sehingga merangsang terbentunya struktur martensit dan karbida chrom.

\section{DAFTAR PUSTAKA}

Adding, F.A., (2010). Pengaruh Temperatur dan Waktu Penahanan Pada Proses Karburasi Padat Baja Karbon Renda. UNHAS, Makasar.

ASM Handbook, (1990). Failure Analysis and Prevention. Vol. 11, ASM International, Material Park, Ohio.

Dwiyati, S.T., Hutomo, B.P., dan Budhi, F., (2019). Pengaruh Variasi Holding Time dan Media Quenching Terhadap Nilai Kekerasan Baja Dengan Kadar Karbon 0,192 wt\%. Jurnal Konversi Energi dan Manufaktur, UNJ, Edisi Terbit I.

Hamzah, S.M., dan Iqbal, M., (2008). Peningkatan Ketahanan Aus Baja Karbon Rendah Dengan Metode Carburizing. Jurnal SMARTek, Vol. 6, pp. 169-175.

Kuswanto, B., (2010). Perlakuan Pack Carburizing Pada Baja Karbon Rendah Sebagai Material Alternatif Untuk Pisau Potong Pada Penerapan Teknologi Tepat Guna. Prosiding Seminar Nasional Sains dan Teknologi, Fakultas Teknik Universitas Wahid Hasyim Semarang.

Palallo, F., (1995). Perlakuan Panas Logam, PPPG Teknologi Bandung.

Rasid, M., Zainuddin, dan Kurniawan M. G. R., (2018). Pengaruh Proses Pack Carburizing Menggunakan Media Batubara Terhadap Kekerasan Pisau Kuduk Khas Daerah Kedung Agung Lahat. Jurnal Austenit, Vol. 10, No. 2.

Saputro, D., Setiadi, G., dan Wibowo, S., (2019). Analisis Pengaruh Waktu Tahan Terhadap Kekerasan Baja AISI 4140 Dengan Metode Karburizing. Jurnal Ilmiah Teknik Mesin, Vol. 7, No. 1, Universitas Islam 45 Bekasi. 
Sukoco, dan Arifin, Z., (2008). Teknologi Motor Disel, Alfabeta, Bandung.

Sunardi, Lusiani, R., Fitra, O.A., (2013). Pengaruh Pack Carburizing dan Kekasaran Permukaan Terhadap Umur Fatik Material Poros Baja S45C. Jurnal Foundry, Vol. 3, pp. 7-12. 


\section{Halaman Ini Dikosongkan}

